\author{
Piotr Stalmaszczyk \\ Uniwersytet Łódzki \\ Instytut Anglistyki \\ ORCID: 0000-0002-1407-7610
}

\title{
Podstawowe zagadnienia współczesnej filozofii języka, filozofii językoznawstwa oraz filozofii lingwistycznej
}

\begin{abstract}
A bstrakt: Celem artykułu jest przedstawienie podstawowych zagadnień współczesnej filozofii języka (zwłaszcza w ujęciu analitycznym) oraz filozofii językoznawstwa i filozofii lingwistycznej, a także relacji między poszczególnymi dyscyplinami. Dla potrzeb niniejszej dyskusji językoznawstwo można określić jako systemowe badanie języka naturalnego, a filozofię języka jako systemowe badanie podstawowych pojęć związanych z naturą i właściwościami języka (zarówno języka naturalnego, jak i języków formalnych). Filozofia językoznawstwa, jako gałąź filozofii nauki, ma za swój przedmiot systemową refleksję nad teoriami językoznawczymi i metodami badań językoznawczych, natomiast filozofia lingwistyczna jest metodą lub techniką badania języka, również języka potocznego. W artykule dokonano również przeglądu zawartości wybranych encyklopedycznych i podręcznikowych pozycji poświęconych filozofii języka.
\end{abstract}

Słow a klucze: filozofia analityczna; filozofia języka; filozofia językoznawstwa; filozofia lingwistyczna; teoria języka; metodologia językoznawstwa; semantyka; pragmatyka

\section{Wstęp}

Poniższe rozważania poświęcone są określeniu zakresu współczesnej analitycznej filozofii języka i do pewnego stopnia także fillozofii językoznawstwa oraz filozofii lingwistycznej, a także uporządkowaniu terminologii i zapro- 
ponowaniu definicji omawianych dyscyplin¹. Rozważania takie mogą być interesujące dla językoznawców, ponieważ pozwalają zobaczyć badania nad współczesną semantyką i pragmatyką z nieco innej perspektywy, a także umożliwiają zapoznanie się z pytaniami (i odpowiedziami) o naturę języka stawianymi przez filozofię (w niniejszym przypadku ograniczoną przede wszystkim do filozofii analitycznej).

Według brytyjskiego filozofa analitycznego, Michaela Dummetta, ,językoznawstwo ogólne wzięło rozbrat z filozofią, która je ukształtowała i w dużej mierze zawładnęło niezależną dziedziną filologii” (Dummett 2010: 8), natomiast według André Comte-Sponville’a lingwistyka powstała na skutek zerwania z filozofią języka (podobnie jak socjologia na skutek zerwania z filozofią społeczną, a psychologia z psychologią podmiotu) ${ }^{2}$. Powołując się na sformułowanie Gastona Bachelarda, Comte-Sponville (2007: 120) mówi w tym kontekście o epistemologicznym cięciu. Dodatkowo, Dummett uważa również, że cała filozofia jest w istocie filozofią języka³ . Nieco inną perspektywę na rozwój fillozofii i nauk szczegółowych przyjmuje filozof Massimo Pigliucci, który zwraca uwagę na to, że w ciągu ostatnich stu lat filozofia musiała na nowo się zdefiniować i samookreślić, czego konsekwencją było powstanie 'różnych filozofii szczegółowych' ('philosophies of...'). Była to też odpowiedź na emancypację poszczególnych gałęzi filozofii - nauka nie jest już filozofią naturalną, co daje możliwość filozofowania na temat nauki (np. biologii, mechaniki kwantowej itd.) bez jednoczesnego uprawiania nauki. To samo dotyczy lingwistyki (i filozofii języka), psychologii (i filozofii nauk społecznych), ekonomii (i filozofii ekonomii) itd. (Pigliucci 2017: 88).

${ }^{1}$ W niniejszym tekście wykorzystuję ustalenia poczynione w rozdziale 4. pracy Stalmaszczyk (2021) oraz w: Stalmaszczyk (w druku). Dziękuję Recenzentom za cenne uwagi i sugestie; ze względu na przeglądowy charakter artykułu nie wszystkie sugerowane zmiany udało mi się wprowadzić (ograniczyłem zwłaszcza polemikę z odmiennymi niż filozofia analityczna stanowiskami badawczymi), z pewnością będą one jednak przydatne przy kolejnej próbie opracowania tematu. Szczególny charakter artykułu uzasadnia również obszerną (choć i tak zdecydowanie nie wyczerpującą) bibliografię przedmiotu.

2 Inaczej wywodzi rodowód językoznawstwa ogólnego Ferdinand de Saussure (1991: 27-32) oraz historiografia językoznawcza.

3 Taką tezę lansował Dummett w większości swoich opracowań, również w jednej ze swoich ostatnich wypowiedzi podkreślił, że w dalszym ciągu traktuje filozofię języka jako podstawę wszelkiej filozofii, zob. Dummett (2012: 21): "I continue to believe that the philosophy of language is the foundation-stone of all philosophy". 
W tym ujęciu filozofia języka jest po prostu szeroko rozumianą filozoficzną refleksją na temat języka (uprawianą niezależnie od językoznawstwa).

Bardzo użytecznym wstępnym określeniem dwóch podstawowych dla niniejszych rozważań dyscyplin posługuje się, wprawdzie w tradycji filozofii hermeneutycznej, ale w duchu bliskim przytoczonym powyżej uwagom, Andrzej Przyłębski, według którego naukowe teorie analizujące język definiują językoznawstwo, natomiast przedmiotem filozofii języka są „rozważania nad fenomenem języka" (Przyłębski 2019: 256) ${ }^{4}$.

Dla potrzeb niniejszej dyskusji można początkowo wyróżnić, oprócz językoznawstwa i filozofii, trzy (częściowo) niezależne dyscypliny5:

- filozofia języka (ang. philosophy of language)

- filozofia lingwistyczna (ang. linguistic philosophy)

- filozofia językoznawstwa (ang. philosophy of linguistics)

Trzy powyższe obszary badawcze pojawiają się w licznych opracowaniach (omawianych poniżej), możliwe są jednak jeszcze inne propozycje podziału odpowiednich domen (czyli językoznawstwa i filozofii) ${ }^{6}$. Ireneusz Bobrowski, w opracowaniach poświęconych przede wszystkim metodologii i filozofii językoznawstwa, wymienia pięć dyscyplin:

- metodologia językoznawstwa (czyli formułowanie kryteriów oceny poszczególnych modeli języka),

- metalingwistyka (analiza prac językoznawczych, krytyka tekstu językoznawczego),

- filozofia językoznawstwa (poszukiwanie filozoficznych podstaw dla przyjmowanych koncepcji językoznawczych),

- filozofia języka (filozoficzne rozważania dotyczące języka naturalnego),

- filozofia lingwistyczna (analiza pojęć i problemów filozoficznych poprzez formalną analizę języka).

${ }^{4}$ Przyłębski (2019) szerzej omawia hermeneutyczne zainteresowanie filozofią języka na przykładzie dokonań Martina Heideggera, Hansa-Georga Gadamera i Paula Ricoeura.

5 Angielskie terminy zostały dodane ze względu na wieloletnią dominację anglo-amerykańskiej literatury na temat filozofii języka i istotnej dla jej rozwoju filozofii analitycznej; terminami ‘językoznawstwo' oraz 'lingwistyka' posługuję się wymiennie, ale z preferencją dla określeń typu 'filozofia lingwistyczna'.

6 Terminem 'dyscyplina' posługuję się tu w sposób intuicyjny, wymiennie z 'obszarem badawczym' i 'dziedziną badań', natomiast ‘domena' ma w tych rozważaniach znaczenie szersze i zawiera w sobie dyscypliny. 
Według krakowskiego badacza, trzy pierwsze obszary przynależą do szeroko pojętej domeny językoznawstwa, natomiast filozofia języka i filozofia lingwistyczna do filozofii ${ }^{7}$. Klasyfikacja wspomnianych obszarów badawczych wyglądałaby następująco:

- domena językoznawstwa

- metodologia językoznawstwa

- metalingwistyka

- filozofia językoznawstwa

- domena filozofii

- filozofia języka

- filozofia lingwistyczna

Dyskusja dotycząca (nie)zależności powyższych dyscyplin ma siłą rzeczy charakter filozoficzny, a jak zauważają Ernest Lepore i Barry Smith (2006: vii), już samo postawienie pytania o to, czym jest filozofia języka, może grozić ryzykiem narzucenia apriorycznego wyodrębniania i rozgraniczenia przedmiotów badań.

Ponadto, na przecięciu dwóch głównych domen możliwe jest wyodrębnienie jeszcze jednej dyscypliny: językoznawstwa filozoficznego / lingwistyki filozoficznej (philosophical linguistics). Temu obszarowi poświecono w polskim i światowym piśmiennictwie, zarówno językoznawczym, jaki i filozoficznym, zdecydowanie mniej uwagi. Według Kashera i Lappina (1977: iii) jest to filozoficzne podejście do objaśniania badań językoznawczych, co zdaje się zbliżać ją do filozofii językoznawstwa, natomiast według Swiggersa (1996: 3) dziedzina ta uwzględnia również kwestie metodologiczne oraz epistemologiczne, a także teorię znaczenia i odniesienia oraz teorię komunikacji, co z kolei upodabnia ją do filozofii lingwistycznej. Można tu jeszcze wspomnieć o 'gramatyce filozoficznej', nawiązującej do scholastycznych gramatyk spekulatywnych, kartezjańskiej gramatyki racjonalnej i ukoronowanej dokonaniami późnego Wittgensteina, zob. np. Rotter $(1997,2006)$.

7 Zob. szerzej na ten temat Bobrowski (2011, 2015), a zwłaszcza Bobrowski (2020). Szereg uwag krytycznych i terminologicznych formułuje także Słapek (2017). 


\section{Filozofia języka, filozofia językoznawstwa, filozofia lingwistyczna}

Poniższe omówienie ogranicza się do wybranych reprezentatywnych publikacji przeglądowych, a także podręcznikowych i encyklopedycznych opracowań dotyczących przede wszystkim filozofii języka, ale również wybranych prac z zakresu filozofii językoznawstwa oraz filozofii lingwistycznej (w rozumieniu wprowadzonym powyżej) ${ }^{8}$.

Barbara Stanosz rozpoczyna swoje wykłady z filozofii języka stwierdzeniem, że „w kręgach filozofów analitycznych formułuje się czasami tezę, iż cała filozofia jest w istocie filozofią języka, mimo że nie wszyscy filozofowie są tego świadomi" (Stanosz 1991: 7). Taką tezę podtrzymuje Michael Dummett, jej zwolennikiem był też początkowo Richard Rorty (zob. poniżej), przeciwnego zdania są natomiast John Searle, zwłaszcza w nowszych publikacjach dotyczących filozofii umysłu, późny Rorty, a także Timothy Williamson czy Herman Cappelen. Stanosz określa filozofię języka w następujący sposób:

(...) filozofię języka stanowi ta część filozofii analitycznej, która podejmuje problemy dotyczące znaczenia słów i zwrotów odnoszących się do języka i jego składników, ich własności i relacji zachodzących pomiędzy nimi, funkcji, które pełnią itp. Tak więc, do filozofii języka należy analiza takich pojęć, jak sensowność i brak sensu, prawda, znaczenie i odnoszenie się do, wynikanie i sprzeczność, stwierdzanie i wyrażanie itp. (Stanosz 1991: 8).

W swoich wykładach Stanosz proponuje węższe ujęcie, związane z konstrukcją teorii języka, rozumianej jako „teoria wyjaśniająca zjawisko komunikowania się ludzi za pomocą systemów umownych znaków (przede wszystkim zwykłych języków etnicznych), zbudowaną na wzór innych teorii empirycznych" (Stanosz 1991: 8). To podejście wskazuje na ścisłe związki zachodzące pomiędzy filozofią języka a semiotyką oraz ważną rolę pragmatyki.

Ian Mackenzie (1997) we wstępie do opracowania z zakresu filozofii lingwistycznej określa przedmiot interesujących nas dyscyplin w sposób nastę-

${ }^{8}$ Należy wyraźnie podkreślić, że przedmiotem zainteresowania jest tu przede wszystkim filozofia analityczna. Historyczne uwarunkowania rozwoju współczesnej filozofii języka przedstawia m.in. Prechtl (2007), a w innej perspektywie Andrzejewski (2016) oraz Szołtysek (2021). 
pujący: językoznawstwo zajmuje się empirycznymi badaniami języka, zadaniem filozofii języka jest wgląd w podstawową istotę zjawisk badanych przez językoznawstwo, natomiast filozofia lingwistyczna stanowi pewnego rodzaju podejście do filozofii języka. Mackenzie (1997: ix) twierdzi, że owo podejście do filozofii języka najlepiej ilustrują Dociekania filozoficzne Wittgensteina, a zwłaszcza przedstawiony tam sposób analizowania języka w użyciu (czyli prymat badania użycia nad analizowaniem struktur logicznych) ${ }^{9}$. Podobnie uważa John Searle (1987: 14), który rozróżnia filozofię języka postrzeganą jako dziedzina badań oraz filozofię lingwistyczną, czyli metodę prowadzenia tych badań (zob. szerszą dyskusję poniżej). Natomiast Zeno Vendler (1974) określa cel filozofii lingwistycznej jako wszelkie badania prowadzone w związku ze strukturą i funkcjonowaniem języków, zarówno naturalnych, jak i sztucznych (i przywołuje przykłady tak różne, jak metafizyczne pisma Arystotelesa, teoria deskrypcji Bertranda Russella czy prace Gilberta Ryle’a dotyczące pojęć) ${ }^{10}$. Vendler wyróżnia jeszcze filozofię językoznawstwa, zajmującą się filozoficznym namysłem nad takimi pojęciami, jak znaczenie, synonimia, parafraza, składnia, tłumaczenie, oraz badaniem logicznego statusu teorii lingwistycznych. Tak rozumiana filozofia językoznawstwa jest jedną z gałęzi bardziej ogólnej filozofii nauk (tak jak np. filozofia fizyki czy filozofia psychologii).

Według Vendlera filozofia języka zajmuje się filozoficznym namysłem nad językiem, czyli problemami takimi jak związek pomiędzy językiem a rzeczywistością. Do prac z zakresu filozofii języka Vendler zalicza, między innymi, książkę Benjamina Lee Whorfa Język, myśl i rzeczywistość, a także - choć z pewnym wahaniem - Tractatus Logico-Philosophicus Ludwiga Wittgensteina (zob. Vendler 1974: 5-6). Vendler omawia krytycznie redukcjonistyczne poglądy Fodora i Katza (1962), według których filozofia języka to nic innego jak filozofia językoznawstwa; a filozofię lingwistyczną mogłoby zastąpić 'naukowe językoznawstwo' (Vendler 1974: 3-4). Co ciekawe,

9 Podobnie postrzega filozofię lingwistyczną Apel (1967) - jako zapoczątkowaną przez późnego Wittgensteina i kontynuowaną przez badaczy z Oksfordu i Cambridge. W swojej rekonstrukcji filozofii analitycznej Apel wyróżnia trzy okresy: logiczny atomizm, pozytywizm logiczny oraz analityczną filozofię języka.

${ }^{10}$ Do tak rozumianej filozofii lingwistycznej Zeno Vendler zalicza również swoją własną pracę, Linguistics in Philosophy, w której stara się wyciągnąć „,filozoficzne wnioski na podstawie różnych zastosowań językoznawstwa strukturalnego" (Vendler 1974: 1). 
sam Vendler prognozuje, że w przyszłości naukowe językoznawstwo wraz z filozofią językoznawstwa mogłyby zastąpić filozofię języka, podobnie jak nauki fizyczne razem $\mathrm{z}$ filozofią nauki zastąpiły kosmologiczne spekulacje z przeszłości (zob. Vendler 1974: 6). Jednakże rozwój językoznawstwa, a przede wszystkim filozofii języka, wykazał błędność przekonań Vendlera: językoznawstwo nie zastąpiło filozofii języka, a w dłuższej perspektywie historycznej można mówić o wzajemnej inspiracji badawczej.

Termin 'zwrot lingwistyczny (w filozofii)' kojarzy się przede wszystkim z nazwiskiem Richarda Rorty'ego i mimo, że to nie on był autorem tego terminu $^{11}$, to zredagowana przez Rorty'ego antologia pod tytułem The Linguistic Turn. Essays in Philosophical Method (1967) na trwałe wprowadziła w obieg filozoficzny i pozafilozoficzny zainteresowanie zwrotem lingwistycznym. W eseju wstępnym do tego tomu Rorty określa filozofię lingwistyczną jako pogląd na naturę problemów filozoficznych, według którego takie problemy mogą być rozwiązane lub usunięte albo poprzez reformę języka, albo przez lepsze zrozumienie użyć języka (Rorty 1967: 3). Pobrzmiewają w tym sformułowaniu zarówno echa drugiej filozofii Wittgensteina, gdzie w centrum zainteresowania znajduje się właśnie użycie języka, prowadzące do zidentyfikowania problemów filozoficznych z problemami językowymi, jak i poglądy Alfreda Ayera, wyrażone w niezwykle ważnej dla rozwoju filozofii analitycznej książce Language, Truth and Logic (wydanej w 1936 r.). Według Ayera analityczne podejście do filozofii oznacza, że filozof nie zajmuje się bezpośrednio fizycznymi właściwościami rzeczy, a jedynie sposobami mówienia o rzeczach, a twierdzenia filozoficzne mają charakter lingwistyczny, a nie faktyczny. Takie sądy, według Ayera, nie opisują zachowań przedmiotów fizycznych ani nawet przedmiotów mentalnych, wyrażają natomiast definicje i formalne konsekwencje definicji, zob. Ayer (2001: 44). Timothy Williamson (2004: 106) określa podejście Ayera mianem „bezwzględnie formalnej wersji filozofii lingwistycznej"'12.

11 Jak zauważa Rorty (1967: 9, przypis 10), twórcą tego terminu był Gustav Bergmann.

12 Po latach Rorty krytycznie odniósł się do swoich wcześniejszych przemyśleń na temat zwrotu lingwistycznego, zob. przedmowę do wznowienia słynnego tomu The Linguistic Turn (Rorty 1992); z perspektywy czasu krytycznie o zwrocie lingwistycznym wypowiadają się m.in. Cappelen (2017) i Williamson (2004). Williamson podkreśla, że nie wszystkie problemy filozoficzne są związane z językiem albo myślą. 
W książce Czynności mowy (pierwsze wydanie z 1969 r.), z wielce znaczącym podtytułem Rozważania z filozofii języka, John Searle wśród pytań wyznaczających dziedzinę filozofii języka wymienia następujące: ,jjak słowa odnoszą się do świata? (...) Jak słowa zastępują rzeczy? Jaka jest różnica między sensownym a bezsensownym szeregiem słów? Na czym to polega, że coś jest prawdą lub że jest fałszem?” (Searle 1987: 13). W dalszej części tych wstępnych rozważań Searle rozróżnia filozofię języka oraz fỉlozofię lingwistyczną, w widoczny sposób nawiązując do brytyjskiej szkoły filozofii języka potocznego:

Filozofia lingwistyczna to próba rozstrzygania określonych zagadnień filozoficznych, odwołująca się do śledzenia potocznego użycia poszczególnych słów lub innych składników danego języka. Filozofia języka to próba podawania filozoficznie rozjaśniających opisów pewnych ogólnych cech języka, jak odnoszenie się wyrażeń, prawda, znaczenie i konieczność. (...) „Filozofia lingwistyczna” to przede wszystkim nazwa metody, „filozofia języka” to nazwa dziedziny. (Searle 1987: 14)

Searle określa swoją książkę jako esej z zakresu filozofii języka (a nie filozofii lingwistycznej lub językoznawstwa). Warto jeszcze przytoczyć definicję językoznawstwa podaną w tym miejscu przez Searle'a: „Językoznawstwo usiłuje opisać rzeczywiste struktury - fonologiczne, składniowe i semantyczne - naturalnych języków ludzkich" (Searle 1987: 13). Oczywiście językoznawstwo generatywne, którego przedmiotem badań jest kompetencja językowa, ma inne ambicje: opisać i uzasadnić możliwe struktury języka ludzkiego (zob. poniżej uwagi na temat 'teorii języka') $)^{13}$. Jest to jednak inne pojmowanie uniwersalności niż to przypisywane przez Searle’a 'danym' filozofii języka.

Postulowane przez Searle'a rozróżnienie dziedziny i metody nie jest powszechnie akceptowane (bądź nie jest uznawane za istotne). Na przykład Je-

13 W tym miejscu zwracam uwage jedynie na charakterystycznie pojmowane przez generatywizm znaczenie uniwersalności i możliwości zaistnienia określonych gramatyk i struktur językowych. Szerzej na temat filozoficznych i metodologicznych założeń językoznawstwa generatywnego zob. np. Chomsky (1982, 1986, 2002, 2016). O historycznych i metodologicznych uwarunkowaniach generatywizmu wspominam w: Stalmaszczyk (2011), a o paradygmatach językoznawstwa generatywnego w: Stalmaszczyk (2018b). 
rzy Bańczerowski, Jerzy Pogonowski i Tadeusz Zgółka twierdzą, że filozofię języka można

(...) interpretować jako tzw. filozofię lingwistyczną, tzn. orientacje stricte filozoficzną, na gruncie której postuluje się rozpatrywanie wszystkich kwestii filozoficznych przez pryzmat języka. Można mianowicie założyć, że w języku (in abstracto) zawiera się cała wiedza o świecie. (...) Jest to program wyrażany w lapidarnym haśle „filozofia jako analiza języka”. (Bańczerowski i in. 1982: 73-74)

Poznańscy autorzy słusznie zwracają uwagę na znaczenie analizy języka dla rozwoju filozofii, jednakże w przyjętym przeze mnie podejściu (inspirowanym w tym przypadku raczej postulatem Searle’a) zdecydowanie nie zrównuję dziedziny i metody.

Według cytowanego już powyżej Ireneusza Bobrowskiego (2011, 2015, 2020) filozofia języka jest najszerszym obszarem badawczym i podejmuje filozoficzne rozważania dotyczące języka naturalnego, filozofia lingwistyczna zajmuje się analizą pojęć i problemów filozoficznych poprzez formalną analizę języka ${ }^{14}$, natomiast filozofia językoznawstwa poszukuje filozoficznych podstaw dla przyjmowanych koncepcji językoznawczych (i dlatego, według tego badacza, przynależy do szeroko pojmowanej domeny językoznawstwa). Należy tu wyraźnie podkreślić, że ustalenia Bobrowskiego są inspirowane między innymi racjonalizmem Izydory Dąmbskiej, podejściem fenomenologicznym Edmunda Husserla i falsyfikacjonizmem Karla Poppera, natomiast w niniejszym artykule nawiązuję przede wszystkim do dziedzictwa neopozytywizmu i do współczesnej filozofii analitycznej.

W niniejszych rozważaniach postrzegam filozofię językoznawstwa jako należącą raczej do filozofii nauk szczegółowych (obok m.in. filozofii matematyki, filozofii psychologii, filozofii antropologii), co zgodne jest z przytoczonym powyżej podejściem Vendlera (1974), a także z definicją zaproponowana w Stanfordzkiej Encyklopedii Filozofii, według której filozofia językoznawstwa jest filozofią nauki zastosowaną do językoznawstwa, co odróżnia ją od filozofii języka, tradycyjnie zorientowanej na kwestie znaczenia i odniesienia (zob. Scholz, Pelletier, Pullum 2020).

14 Por. również ustalenia na temat filozofii lingwistycznej w: Hallett (2008). Hallett wychodzi w swych ustaleniach poza filozofię analityczną i filozofię języka potocznego i traktuje filozofię lingwistyczną jako nowy sposób uprawiania filozofii. 
Wśród obszarów badawczych w obrębie filozofii języka można jeszcze wyodrębnić ontologię języka i epistemologię języka. Ontologia języka jest tu rozumiana, za Andrzejem Biłatem, jako zespół „specyficznych zagadnień, istotnie wzbogacających pragmatyczną problematykę (okazjonalności, postaw zdaniowych, presupozycji, implikatury, aktów mowy itd.), typową dla (analitycznej) filozofii języka ostatnich dziesięcioleci” (Biłat 2010: 12), natomiast epistemologia języka podejmuje zagadnienia związane z rolą języka w poznaniu, co zbliża ją do niektórych założeń współczesnej kognitywistyki.

Domenę językoznawstwa można dodatkowo uzupełnić o teorię języka, rozumianą w duchu Noama Chomsky’ego, czyli jako próbę odzwierciedlenia przez językoznawców nieuświadomionej wiedzy językowej ${ }^{15}$. W szerzej rozumianej teorii języka można natomiast wyodrębnić tradycyjne obszary składni, semantyki i pragmatyki (pomijam tu fonologię).

\section{Definicje i domeny}

Podsumowując powyższą dyskusję oraz dla potrzeb dalszych rozważań przyjmuję, że w domenie fillozofii rozwija się filozofia języka i filozofia językoznawstwa. Przyjmuję też, za Searlem, że filozofia lingwistyczna jest pewną metodą filozofii języka. Przy założeniu, że przedmiotem językoznawstwa jest system językowy, a także gramatyczna oraz pragmatyczna kompetencja językowa, samo językoznawstwo można określić jako systemowe badanie języka naturalnego, natomiast filozofię języka, w ujęciu analitycznym, można określić jako systemowe badanie podstawowych pojęć związanych z naturą i właściwościami języka (języka naturalnego i języków formalnych) ${ }^{16}$. Filo-

15 Teoria języka „traktowana jako hipoteza w wrodzonej 'zdolności językotwórczej' istot ludzkich powinna zajmować się uniwersaliami zarówno materialnymi, jak i formalnymi” (Chomsky 1982: 52). Jest to inne rozumienie teorii języka niż proponowane przez Stanosz (1991: 8), por. powyżej, a także przez Szołtyska (2021). Według Szołtyska (2021: 202) „filozofia języka wyznacza możliwe źródła i granice uniwersalnej teorii języka".

16 Takie podejście (szczególnie kluczowe odniesienie do 'systemowości') przyjmuję i uzasadniam w: Stalmaszczyk (w druku). Jak zauważył jeden z Recenzentów, szersze rozumienie filozofii języka, jako filozoficznej refleksji o języku o charakterze ontologiczno-epistemologicznym, pozwoliłoby na uwzględnienie perspektywy fenomenologicznej (zaproponowanej przez Husserla i jego kontynuatorów), a także postawy filozoficzno-językowej związanej z ontologią fundamentalną Martina Heideggera oraz nurtem filo- 
zofia językoznawstwa jako gałąź filozofii nauki jest systemową refleksją nad teoriami językoznawczymi i metodami badań językoznawczych, natomiast filozofia lingwistyczna jest metodą lub techniką badania języka, również języka potocznego. Metodologia językoznawstwa zajmuje się formułowaniem kryteriów oceny poszczególnych teorii i modeli języka. Relacja pomiędzy poszczególnymi dyscyplinami wygląda zatem następująco (przy czym filozofia lingwistyczna jest metodą uprawiania filozofii, a ontologia i epistemologia języka to refleksja nad, odpowiednio, sposobem istnienia języka oraz sposobem jego poznawania):

- domena filozofii

- filozofia języka

- filozofia lingwistyczna

- ontologia języka

- epistemologia języka

- filozofia językoznawstwa

- domena językoznawstwa

- teoria języka

- składnia

- semantyka

- pragmatyka

- metodologia językoznawstwa

- metalingwistyka

- (lingwistyka filozoficzna)

Powyższy schemat nie jest, z oczywistych względów wyczerpujący, wymienia jedynie obszary badawcze istotne dla niniejszych rozważań. Możliwym dopełnieniem tego schematu byłoby uwzględnienie również domeny logiki (dla potrzeb dyskusji sztucznie wydzielonej z filozofii), a w niej wyszczególnienie semiotyki logicznej, czyli logicznej teorii języka i jej odrębnych trzech działów ${ }^{17}$ :

zofii hermeneutycznej oraz postheglowskiej (reprezentowanej przez Roberta Brandom). W niniejszym przeglądzie zagadnień zdecydowałem się jednak na zawężone podejście, akcentujące przede wszystkim dokonania analitycznej filozofii języka.

17 Przyjmuję tu tradycyjną - podręcznikową - klasyfikację za Woleńskim (2014: 183-184), por. też Woleński (2019), dopełnioną o teorię argumentacji (retorykę logiczną), zob. Kwiatkowski (2002). Według Kwiatkowskiego (2002: 16) teoria argumentacji ma za przedmiot dyskursywne środki przekonywania. Natomiast według Kmity (1975) 
- domena logiki

- semiotyka logiczna (logiczna teoria języka)

- syntaktyka (składnia logiczna)

- semantyka

- pragmatyka

- logika formalna

- ogólna metodologia nauk

- teoria argumentacji (retoryka logiczna)

Jak widać z powyższych klasyfikacji, składnia, semantyka i pragmatyka są przedmiotem badań zarówno językoznawczych, jak i logicznych, co czyni je również istotnymi obszarami dla filozofii języka.

Kończąc powyższą dyskusję nad różnymi domenami i dyscyplinami, chciałem przedstawić jeszcze kilka uwag porządkujących: w idealnej konfiguracji, filozofia języka stanowi namysł nad językiem, filozofia językoznawstwa stanowi namysł nad pojęciami i teoriami językoznawczymi, filozofia lingwistyczna stanowi sposób uprawiania filozofii, natomiast lingwistyka filozoficzna jest sposobem uprawiania lingwistyki (z zastosowaniem metod wypracowanych przez filozofię). W rzeczywistości te dwa ostatnie obszary badań dość mocno się na siebie nakładają, a i przedmiot filozofii języka czasem niełatwo odróżnić od filozofii językoznawstwa. Pewnym przybliżeniem problemu dokładnego wydzielenia odpowiednich obszarów badawczych byłoby porównanie możliwych (znów: idealnych) relacji zachodzących pomiędzy człowiekiem (jako obiektem badań), antropologia (jako uogólnioną nauką 'o człowieku') i filozofia - można wtedy wyróżnić: fillozofię człowieka, filozofię antropologii, filozofię antropologiczną oraz antropologię filozoficzna. W rzeczywistości, w licznych opracowaniach filozofia człowieka oraz

na logikę składają się dwa działy: logiczna teoria języka (czyli logika w węższym znaczeniu, logika formalna) oraz logiczna teoria nauki. W tym ujęciu teorię języka wyczerpuje składnia logiczna i semantyka logiczna (Kmita 1975: 77). Wyraźnie widać, że wszelkie klasyfikacje i podziały dyscyplin są do pewnego stopnia arbitralne, zob. też Ajdukiewicz (1975), Kotarbiński (1961), Ziembiński (2002). Woleński wspomina również o traktowaniu nazw 'semiotyka' i 'semantyka' za ,(niemal) synonimy” (Woleński 2019: 232), ponadto, jak zwraca uwagę ten autor, istnieją zauważalne 'narodowe' tradycje terminologiczne - „w polskiej tradycji semantyka [czyli tu: semiotyka, dopisek mój P.St.] należy do logiki (w szerokim) znaczeniu, obok logiki formalnej (logika w węższym znaczeniu) i metodologii nauk" (Woleński 2019: 232). Zob. też rozważania, z nieco innej perspektywy, na temat 'języka logiki’ i ‘języka lingwistyki’ w: Tałasiewicz (2006). 
antropologia filozoficzna są utożsamiane, zob. dyskusję i odniesienia bibliograficzne w: Darowski (2008).

Nie było moją intencją przytoczenie wyczerpującej listy definicji ani możliwych klasyfikacji dyscyplin ${ }^{18}$, interesują mnie raczej możliwe spojrzenia na badanie języka w obrębie i na przecięciu językoznawstwa, analitycznej filozofii języka (oraz do pewnego stopnia logiki), ze szczególnym uwzględnieniem wybranych podejść do semantyki i pragmatyki.

\section{Współczesna filozofia języka: przegląd zagadnień}

Nie przesądzając o słuszności rozróżnień omawianych powyżej, warto zauważyć, że według najnowszych opracowań dotyczących filozofii języka, jej podstawowe pytania nieodmiennie dotyczą znaczenia i związków zachodzących pomiędzy językiem a myślą (Devitt i Hanley 2006: 1-2), jak też problemów znaczenia, rozumienia i komunikacji (Davies 2006: 29), a filozofów interesują przede wszystkim trzy szerokie obszary języka - składnia, semantyka i pragmatyka (Martinich 2009: 1). Peter Prechtl jako podstawowe zagadnienie uważa określenie stosunku: ,język - myślenie - rzeczywistość" (Prechtl 2007: 10) ${ }^{19}$. Dla Michaela Morrisa trzy podstawowe pytania filozofii języka to: Czym jest język? Jak słowa nabierają znaczeń? Jakie jest znaczenie słów? (Morris 2007: 3). Chris Daly (2013: 1-11) poszerza listę pytań do dziesięciu i uwzględnia m.in. pytania o relację pomiędzy znaczeniem a prawdą, znaczeniem a myślą oraz o rolę kontekstu i czynników pragmatycznych w analizach filozoficznych. Miguel García-Carpintero (2012: 2-3) wspomina o relacjach pomiędzy znaczeniem, modalnością i rozumieniem tych zjawisk jako podstawowych pojęciach filozofii języka, wywodzących się jeszcze z (możliwego odczytania) Traktatu Wittgensteina. Według Scotta Soamesa do podstawowych pojęć filozofii języka (tak jak i całej filozofii) należą prawda, odniesienie, znaczenie, możliwość, sąd oraz implikatura, Soames zwraca także uwagę na wręcz majeutyczny charakter filozofii języka, zwłaszcza w odniesieniu do naukowych badań nad językiem (zarówno ję-

18 Nieco szerzej omawiam te zagadnienia w: Stalmaszczyk (2021).

19 W swojej autorskiej koncepcji filozofii języka Alfred Szołtysek wprowadza dwie inne triady: „myślenie - język - mówienie” oraz „umysł - język - mózg”, zob. Szołtysek (2021). 
zykiem naturalnym, jak i językami formalnymi) i użyciem języka (Soames 2010: 1), natomiast Alex Miller otwiera swoje podręcznikowe opracowanie stwierdzeniem, że filozofia języka jest motywowana chęcią systemowego uzasadnienia naszych intuicji dotyczących pojęcia znaczenia, zob. Miller (2018: 8). O weryfikowaniu intuicji jako problemie współczesnej filozofii języka wspominają również Devitt i Hanley (2006: 1-2).

W ujęciu Michaella Dummetta pojęcia znaczenia i prawdy mają charakter pomostowy: pojęcie znaczenia stanowi pomost pomiędzy filozofią języka a filozofią myśli (umysłu), natomiast pojęcie prawdy stanowi pomost pomiędzy filozofią języka a metafizyką, obydwa te pojęcia są ze sobą nierozerwalnie związane (Dummett 2012: 21). Uwaga Dummetta wskazuje przy okazji na miejsce filozofii języka pośród innych filozoficznych dziedzin, a także na jej nieredukowalność do innych dziedzin filozofii.

Warto w kontekście dyskusji dotyczącej przedmiotu współczesnej filozofii języka pokrótce przyjrzeć się zawartości kilku niedawnych publikacji o charakterze encyklopedycznym i przeglądowym: The Blackwell Guide to the Philosophy of Language (Devitt i Hanley (red.) 2006), Blackwell Companion to the Philosophy of Language (2 wydanie, Hale, Wright, Miller (red.) 2017), The Oxford Handbook of Philosophy of Language (Lepore i Smith (red.) 2006), The Routledge Companion to Philosophy of Language (Russell i Graff Fara (red.) 2012), oraz dwóm najnowszym podręcznikom filozofii języka autorstwa Zoltána Szabó i Richmonda Thomasona (2019) i Mitchella Greena $(2020)^{20}$.

Przewodnik wydawnictwa Blackwell (Blackwell Guide) przynosi 20 rozdziałów podzielonych na trzy podstawowe części: zagadnienia podstawowe (rozdział o charakterze programowym w znacznej części poświęcony problemom badania znaczenia, kontrastujący program Davidsona z podejściem Grice'a), znaczenie (rozdziały dotyczące m.in. semantyki formalnej, rozróżnienia pomiędzy analitycznością a syntetycznością, aktów mowy i pragmatyki, języka figuratywnego, okresów warunkowych w logice i języku, zjawiska

${ }^{20}$ Recenzent artykułu sugerował wyraźniejsze oddzielenie definicyjnych propozycji podręcznikowych i encyklopedycznych od tych obecnych w technicznej literaturze przedmiotu. Jednakże wybrane przeze mnie publikacje encyklopedyczne oraz podręczniki w zdecydowanej większości można również traktować jako (techniczne) głosy we współczesnej debacie, ponadto przynoszą one istotne ustalenia historyczno-terminologiczne. 
nieostrości) oraz odniesienie (z rozdziałami podejmującymi takie zagadnienia, jak: nazwy, deskrypcje, zaimki i anaforyczność oraz prawda). Kolejny przewodnik wydawnictwa Willey-Blackwell (Companion) podzielony jest na dwa obszerne tomy. 19 rozdziałów w pierwszym tomie przedstawia panoramę tematów związanych ze znaczeniem i teoriami znaczenia, natomiast drugi tom przynosi dwie części (w sumie 21 rozdziałów), poświęcone relacjom pomiędzy językiem, prawdą i rzeczywistością oraz szczegółowym zagadnieniom związanym z odniesieniem, identycznością i koniecznością.

Natomiast w tomie wydawnictwa oksfordzkiego 41 rozdziałów składa się na siedem części poświęconych kolejno kontekstowi historycznemu (przede wszystkim koncepcjom Fregego i Wittgensteina), naturze języka, naturze znaczenia, naturze odniesienia, teorii semantycznej, różnym zjawiskom lingwistycznym (takim jak m.in. czas, liczba, kwantyfikatory), różnorodności aktów mowy oraz epistemologii i metafizyce języka. Przewodnik wydawnictwa Routledge przynosi przeszło 70 rozdziałów podzielonych na części dotyczące zagadnień podstawowych (m. in. presupozycja, implikatura, fokus i intonacja, teoria relewancji), podstaw semantyki, odrębnej części poświęconej ‘częściom mowy’ (oprócz 'klasycznych’ części mowy są tu omówione także problemy takie jak anafora, pytania, wyrażenia generyczne), części metodologicznej, części dotyczącej logiki dla filozofów języka, historycznych perspektyw oraz części dotyczącej relacji pomiędzy filozofią języka a pozostałą filozofią (z rozdziałami na temat m.in. języka i rasy, języka i płci). W tym tomie wyraźnie widać silny splot tematów z pogranicza filozofii i językoznawstwa, a autorzy poszczególnych rozdziałów chętnie sięgają po dokonania lingwistyczne.

Zaawansowany podręcznik filozofii języka, autorstwa Zoltána Szabó i Richmonda Thomasona (2019), wydany w serii Cambridge Textbooks in Linguistics, stawia w centrum rozważań problem znaczenia. Kolejne części książki podejmują kwestie filozofii semantyki (w tym zagadnienia kompozycjonalności, odniesienia, kwantyfikacji, czasu i modalności, intencjonalności), filozofii pragmatyki (kontekst i zawartość wypowiedzi, implikatury i wypowiedzi figuratywne, asercja i inne akty mowy), oraz znaczenia jako zagadnienia filozoficznego (ze zwróceniem uwagi na rozróżnienie znaczenia i użycia, paradoksów, nieostrości oraz podejść internalistycznych i eksternalistycznych do znaczenia). W części dotyczącej pragmatyki autorzy zwracają uwagę na specyficzny typ powiększenia pola pragmatycznego (pragmatic 
augmentation), które czyni pragmatykę czymś więcej niż rozszerzoną wersją semantyki formalnej. Podręcznik Mitchella Greena (2020) nie jest tak zaawansowany i wprowadza szereg tematów z pogranicza semantyki i pragmatyki - oprócz rozdziałów poświęconych znaczeniu (również z perspektywy językoznawczej) są to rozdziały poświęcone aktom mowy i konwersacji, roli kontekstu, implikatury i presupozycji, a także dyskursowi oczerniającemu (despicable discourse), a także dyskursowi fikcji, metaforze, ironii, znaczeniom przenośnym. Nawet ten krótki przegląd zawartości pokazuje, że znaczna część rozdziałów podręcznika Greena mogłaby znaleźć się w podręczniku pragmatyki.

Ważną publikacją w języku polskim było 10 wykładów z filozofii języka Barbary Stanosz (1991), wspomnieć należy również o dwóch publikacjach zbiorowych w języku polskim: o wyborze przekładów pt. Filozofia języka (Stanosz (red.) 1993), oraz Przewodniku po filozofii języka (Odrowąż-Sypniewska (red.) 2015). Tom pod redakcją Barbary Stanosz, w planowanej, ale tylko częściowo zrealizowanej serii „fragmentów filozofii analitycznej”, przynosi 15 kluczowych tekstów podzielonych na cztery części: (1) znaczenie, prawda i komunikacja, (2) prawda, gramatyka i logika, (3) przekład i znaczenie, oraz (4) przyczynowa teoria referencji. Niektóre z tych tekstów i przedstawione w nich kontrowersje mają w tej chwili już jedynie historyczne znaczenie, ale większość należy do klasyki ciągle czytanej i na nowo odczytywanej. Zdecydowanie nowszy Przewodnik po filozofii języka (wydany w serii Wydawnictwa WAM Przewodniki po filozofii) dzieli omawiany materiał na cztery zasadnicze części ('Znaczenie i odniesienie', 'Język i prawda', 'Sąd logiczny', 'Pragmatyka' oraz 'Spory współczesne'), a kolejne rozdziały przedstawiają zagadnienia związane z następującymi tematami: znaczenie, analityczność, odniesienie, nazwy własne, deskrypcje, sądy, okazjonalność, nieostrość, minimalizm semantyczny i kontekstualizm, internalizm i eksternalizm semantyczny, realizm i antyrealizm semantyczny, akty mowy, implikatury, metafora i ironia. Dla rozważań z pogranicza językoznawstwa najciekawsze są ostatnie $\mathrm{z}$ wymienionych tematów, ale również rozdziały traktujące o znaczeniu, nazwach własnych czy nieostrości, analizują zjawiska interesujące dla semantyki, także semantyki leksykalnej, a przede wszystkim dla współczesnej pragmatyki ${ }^{21}$.

21 Bardziej szczegółowo omawiam zawartość tego tomu w: Stalmaszczyk (2018a). 
Do tradycyjnych obszarów zainteresowania filozofii języka (czyli wymienionej przez Prechtla triady ,język - myślenie - rzeczywistość”) dołączyły również obszary intensywnie badane w ostatnich latach także przez współczesną psychologię, kognitywistykę i neuronauki, czyli na przykład świadomość, stany mentalne, percepcja oraz rola intuicji. Filozofia języka czerpie również inspiracje z ustaleń poczynionych w ramach badań językoznawczych, takich jak np. dokonania oraz implikacje formalnych badań nad językiem (zwłaszcza formalne badania składni), zwrócenie uwagi na rolę kontekstu nie tylko w rozumieniu, ale i w tworzeniu znaczenia (tak jak w semantyce dynamicznej i teorii reprezentacji dyskursu); współczesna filozofia języka wykorzystuje także kognitywne analizy niedosłownego użycia języka i metafor, a także nowe spojrzenie na zjawisko ironii proponowane przez teorię relewancji i badania eksperymentalne. Również językoznawstwo podejmuje zagadnienia o zdecydowanie filozoficznym charakterze, chociażby takie jak badanie relacji pomiędzy językiem a rzeczywistością ${ }^{22}$. Wspólne dla filozofii i językoznawstwa są też choćby pytania o ontologiczny status języka oraz naturę znaczenia, a także nazw własnych i bytów fikcyjnych (stąd wzrost zainteresowania w filozofii języka problemami z pogranicza filozofii literatury).

Ilość nowych publikacji naukowych (w tym także podręczników i wszelkiego rodzaju przewodników encyklopedycznych) i konferencji poświęconych różnym aspektom filozofii języka zdaje się wskazywać na wzrost zainteresowania taką tematyką. Lepore i Smith (2006: viii) po krótkich uwagach na temat zmieniającego się spektrum zainteresowań i pozycji filozofii języka w obrębie innych dyscyplin filozoficznych, zauważają, że podstawowym przedmiotem zainteresowania pozostają pytania dotyczące natury języka i językowych możliwości komunikacji i wyrażania myśli. To poszerzenie pola badawczego współczesnej filozofii języka pozwala na podjęcie proble-

22 Podstawowe pytania dotyczące relacji zachodzących pomiędzy językiem a rzeczywistością są następujące: Czy język odzwierciedla rzeczywistość?, Czy język kreuje rzeczywistość?, Czy język interpretuje rzeczywistość? Zob. jedną z możliwych prób odpowiedzi w: Tokarski (2014: 52-66), z innej perspektywy omawiają te zagadnienia Andrzejewski (2016) i Szołtysek (2021). Por. także koncepcję teorii konstytutywnej (w której język 'ustanawia') w opozycji do teorii instrumentalnej (w której język 'służy') w: Taylor (2016). 
matyki obecnej w badaniach antropologicznych, zwłaszcza w tradycyjnym ujęciu ${ }^{23}$.

\section{Zakończenie}

Podsumowując ten krótki zarys współczesnej analitycznej filozofii języka ${ }^{24}$, można się w pełni zgodzić z Martinichem, który twierdzi, że przed współczesną filozofią języka (mimo że jest ona dyscypliną trudną i techniczną) otwierają się jasne perspektywy (Martinich 2009: 1); wbrew dość kąśliwej uwadze Bryana Magee (1998: 55), że „filozof, który poświęca swe życie trosce o język, jest jak cieśla, który cały swój czas poświęca ostrzeniu narzędzia, a tych nie używa do niczego innego, jak tylko do ostrzenia narzędzi właśnie", współcześni fillozofowie języka dysponują ostrymi narzędziami, które pozwalają na precyzyjną analizę problemów dalece wykraczających poza rozważania metajęzykowe. Michael Devitt i Richard Hanley (2006: 16) zauważają, że współczesna analityczna filozofia języka znacznie wzbogaciła nasze rozumienie świata i języka, w którym o świecie mówimy. Również Gillian Russell (2012: 6) podkreśla precyzyjną ostrość i użyteczność narzędzi wypracowanych przez filozofię języka, ich użyteczność dla innych dyscyplin filozoficznych i stwierdza wręcz, że kto chce dzisiaj być dobrym filozofem, musi porządnie zapoznać się z filozofią języka.

Wcześniej, w cytowanym powyżej fragmencie, Magee (1998: 55) stwierdza, że ,język jest narzędziem i ważne jest, co się z nim robi (...) użytek, jaki się z niego robi przy formułowaniu i dyskutowaniu teorii na temat świata"; prowadzone współcześnie badania doskonale ilustrują meta-instrumentalny charakter filozofii języka.

Warto wspomnieć w tym miejscu o jeszcze innym nurcie istotnym dla współczesnej filozofii języka, ale zdecydowanie rzadziej przywoływanym niż filozofia analityczna czy filozofia języka potocznego, czyli o Szkole Lwowsko-Warszawskiej (reprezentowanej przez Kazimierza Twardowskiego i kolejne pokolenia jego uczniów). Jak dobrze wiadomo, w Szkole zwracano szczególną uwagę na precyzję analiz językowych, a rozwiązań problemów

23 Zob. na przykład sformułowanie Franza Boasa: antropolog jest ,zainteresowany aspektem społecznym zjawiska językowego, językiem jako środkiem komunikacji i wzajemnymi powiązaniami języka i kultury" (Boas 2019: 24).

24 Nieco szerzej piszę na ten temat w zakończeniu w: Stalmaszczyk (2021). 
szukano przede wszystkim na gruncie analiz logicznych ${ }^{25}$. Charakterystyczne dla tego podejścia mogą być następujące trzy fragmenty, przytoczone za monografią Anny Brożek (2020):

Autor nieumiejący myśli swych wyrazić jasno, nie umie też myśleć jasno; (...) więc myśli jego nie zasługują na to, by się silić na ich odgadywanie. (Kazimierz Twardowski, „O jasnym i niejasnym stylu filozoficznym”, 1919, za: Brożek 2020: 73)

Język nie jest tylko narzędziem komunikowania myśli, lecz także narzędziem jej kształtowania. (Tadeusz Czeżowski, „O kulturze logicznej”, 1954, za: Brożek 2020: 119)

Jednym z naczelnych zadań (...) [logiki] jest walka z zamętem (...) głównym narzędziem w walce z zamętem (...) [jest definicja]. (Janina Kotarbińska, „Definicja", 1955, za: Brożek 2020: 171)

Ludwig Wittgenstein chciał, by filozofowie sprowadzali słowa „z ich zastosowań metafizycznych z powrotem do użytku codziennego" (Wittgenstein 2000: § 116), przedstawiciele Szkoły Lwowsko-Warszawskiej wskazywali na precyzyjne analizy logiczne, przynoszące więcej korzyści niż rozważania zwolenników „mętnej głębi” lub „zawieszone w próżni formalizmy” (zob. Brożek 2020: 7).

Jak stosunkowo niedawno zauważył wybitny filozof amerykański, współtwórca teorii aktów mowy i ważnych prac z zakresu filozofii umysłu oraz ontologii społecznej, John Searle, centrum zainteresowania w filozofii przesunęło się obecnie z języka na umysł, między innymi dlatego, że

(...) wiele problemów językowych to szczególne przypadki problemów umysłu. Użytek, jaki czynimy z języka, jest wyrazem bardziej fundamentalnych biologicznie niż sam język zdolności mentalnych, więc żeby w pełni zrozumieć, jak język funkcjonuje, musimy pokazać, jak jest on w tych zdolnościach zakorzeniony. (...) zasadniczym pytaniem filozofii początków XXI wieku jest wyjaśnienie miejsca, jakie zajmujemy my, czyli ewidentnie świadome, myślące, wolne, racjonalne, mówiące, społeczne i polityczne przedmioty w świecie, o którym na-

25 Metodzie badania pojęć w Szkole Lwowsko-Warszawskiej poświęcona jest najnowsza monografia Anny Brożek (2020). 
uka mówi nam, że składa się z bezmyślnych i pozbawionych sensu cząsteczek fizycznych. (Searle 2010: 20)

Podobne uwagi czyni Timothy Williamson, a Herman Cappelen twierdzi wręcz, że filozofia języka wyczerpała już swój potencjał, a zwrot lingwistyczny jest martwy ${ }^{26}$. Argumentacja dotycząca tego, czy ważniejsza w tej chwili jest filozofia języka, czy raczej filozofia umysłu (a także dywagacje dotyczące wzajemnych relacji pomiędzy tymi obszarami) ma jednakże charakter zdecydowanie akademicki, można, na przykład, rozumieć filozofię umysłu szeroko: „włączając do niej co najmniej filozofię języka, teorię znaczenia i filozofię logiki" (Strawson 1994: 92). Strawson najprawdopodobniej chciał tu zwrócić uwagę na płynność granic pomiędzy dziedzinami i pewną arbitralność w ich ustanawianiu, w przedmowie do swojej książki wspomina o „łączących się ze sobą dziedzinach metafizyki, epistemologii i filozofii języka" (Strawson 1994: 5), a omawiając książkę Główne zagadnienia filozofii George’a Moore'a, wspomina jeszcze o relacji zachodzącej pomiędzy logiką (w ujęciu Moore’a) a filozofią języka (1994: 41). Również Ayer w swoim przeglądzie filozofii w XX wieku rozróżnia rozmaite działy filozofii, takie jak logika, teoria poznania, filozofia umysłu, filozofia języka, etyka, polityka, ale jednocześnie podkreśla, że różne kontrowersje i spory dotyczą także tego, czy niektóre dyscypliny zaliczane do szeroko pojętej filozofii (np. metafizyka) stanowią „domenę właściwej działalności filozoficznej” (Ayer 2000: 7); podobnie ostrożnie należy wypowiadać się na temat ostrości granic pomiędzy poszczególnymi dyscyplinami.

Co jednak znacznie ważniejsze, w ostatnich latach można zauważyć wyraźne poszerzenie spektrum tematów badawczych podejmowanych przez filozofię języka (często na styku z badaniami lingwistycznymi), można tu przytoczyć publikacje poświęcone filozofii języka w wymiarze stosowanym oraz eksperymentalnym, w których podejmuje się, przykładowo, analizy niejawnych aktów mowy, a także empiryczne próby weryfikacji intuicji, uzasadniania przekonań i różnych eksperymentów myślowych.

Zamiast o końcu filozofii języka należy raczej mówić o coraz bardziej owocnej współpracy z domenami i dyscyplinami do pewnego stopnia po-

${ }^{26}$ Zob. Williamson (2004: 107): "The philosophy of mind has famously displaced the philosophy of language at the centre of much current debate", także Cappelen (2017: 743): "(...) the linguistic turn is dead. (...) philosophy of language has lost its way". 
krewnymi: filozofią umysłu, filozofią literatury, etyką, teorią argumentacji, szeroko pojętymi naukami kognitywnymi oraz językoznawstwem. Każdy poważny namysł nad istotą języka powinien mieć charakter zarówno językoznawczy, jak i filozoficzny, stąd filozofia języka ma znaczenie dla rozwoju zarówno samej filozofii, jak i językoznawstwa.

\section{Bibliografia}

AJDUKIEWICZ K., 1975, Logika pragmatyczna, Warszawa: PWN.

Andrzejewski B., 2016, Filozofia słowa. Zarys dziejów, Poznań: Wydawnictwo Naukowe UAM.

Ayer A., [1936] 2001, Language, Truth and Logic, London: Penguin Books.

BańcZerowski J., Pogonowski J., ZgóŁKa, T., 1982, Wstęp do językoznawstwa, Poznań: Wydawnictwo UAM.

BiıAT A., 2010, Jaka ontologia języka?, w: P. Stalmaszczyk (red.), Metodologie językoznawstwa. Filozoficzne i empiryczne problemy $w$ analizie języka, Łódź: Wydawnictwo Uniwersytetu Lódzkiego, s. 11-25.

BoAs F., [1928] 2019, Antropologia a życie współczesne (tłum. K. Siekierski), Warszawa: Narodowe Centrum Kultury.

Bobrowski I., 2011, W stronę filozofii językoznawstwa, Prace Filologiczne LX, s. 27-36.

Bobrowski I., 2015, Problems of Methodology and Philosophy in Linguistics, Frankfurt am Main: Peter Lang.

Bobrowski I., 2020, Zagadnienia metodologii i filozofii językoznawstwa, Kraków: Instytut Języka Polskiego PAN.

BrożeK A., 2020, Analiza i konstrukcja. O metodach badań w Szkole Lwowsko-Warszawskiej, Kraków: Copernicus Center Press.

Cappelen H., 2017, Why Philosophers Shouldn't Do Semantics, Review of Philosophy and Psychology 8, s. 743-762.

Chomsky N., [1965] 1982, Zagadnienia teorii składni (tłum. I. Jakubczak), Wrocław: Ossolineum.

Chomsky N., 1986, Knowledge of Language: Its Nature, Origin and Use, New York: Praeger.

Chomsky N., 2002, On Nature and Language, Cambridge: Cambridge University Press.

Сномsкy N., 2016, What Kind of Creatures Are We?, New York: Columbia University Press. 
Comte-Sponville A., [2005] 2007, Filozofia (tłum. E. Burska), Warszawa: Instytut Wydawniczy PAX.

Daly C., 2013, Philosophy of Language. An Introduction, London: Bloomsbury.

Darowski R., [1995] 2008, Filozofia człowieka. Zarys problematyki, Kraków: Wydawnictwo WAM.

DAvies M., 2006, Foundational Issues in the Philosophy of Language, w: M. Devitt, R. Hanley (red.), The Blackwell Guide to the Philosophy of Language, Oxford: Blackwell, s. 19-40.

Devitt M., Hanley R., (red.) 2006, The Blackwell Guide to the Philosophy of Language, Oxford: Blackwell.

Devitt M., Hanley R., 2006, Introduction, w: M. Devitt, R. Hanley (red.), The Blackwell Guide to the Philosophy of Language, Oxford: Blackwell, s. 1-16.

Dummetт M., [2001] 2010, Natura i przyszłość filozofii (tłum. M. Iwanicki i T. Szubka), Warszawa: Wydawnictwo IFiS PAN.

Dummetт M., 2012, The Place of Philosophy in European Culture, European Journal of Analytic Philosophy 8 (1), s. 14-23.

García-Carpintero M., 2012, Editorial Introduction: History of the Philosophy of Language, w: M. García-Carpintero i M. Kölbel, (red.), s. 1-25.

García-Carpintero M., Kölbel M., (red.), 2012, The Continuum Companion to the Philosophy of Language, London: Continuum.

Green M. S., 2020, The Philosophy of Language, New York \& Oxford: Oxford University Press.

Hale B., Wright C., Miller A., (red.), 2017, A Companion to the Philosophy of Language, Second Edition, Oxford: Willey-Blackwell.

Hallett G., 2008, Linguistic Philosophy. The Central Story, Albany, NY: SUNY Press.

Kasher A., LapPin S., 1977, Philosophical Linguistics: An Introduction, Kronberg: Scriptor Verlag.

KмiтA J., 1975, Wyktady z logiki i metodologii nauk, Warszawa: PWN.

KotarbiŃsKi T., [1947] 1961, Przegląd problematyki logiczno-syntaktycznej, w: Elementy teorii poznania, logiki formalnej i metodologii nauk (II wydanie), Wrocław: Zakład Narodowy im. Ossolińskich, s. 473-480.

KwiatKowski T., 2002, Wyklady i szkice z logiki ogólnej, Lublin Wydawnictwo UMCS.

Lepore E., Smith B. C., (red.), 2006, The Oxford Handbook of Philosophy of Language, Oxford: Oxford University Press.

Lepore E., Smith B. C., 2006, Preface, w: E. Lepore, B. C. Smith (red.), The Oxford Handbook of Philosophy of Language, Oxford: Oxford University Press, s. vii-X. 
MackenzIe I., 1997, Introduction to Linguistic Philosophy, Thousand Oakes: Sage Publications, Inc.

Magee B., [1973] 1998, Popper (tłum. P. Dziliński), Warszawa: Prószyński i Ska.

Martinich A. P., (red.), 2009, Philosophy of Language. Critical Concepts in Philosophy. Volumes $I-I V$, London and New York: Oxford University Press.

Martinich A. P., 2009, General Introduction, w: A. P. Martinich (red.), Philosophy of Language. Volume 1, London and New York: Oxford University Press, s. 1-18.

Miller A., [1998] 2018, Philosophy of Language. Third edition, New York: Routledge.

Morris M., 2007, An Introduction to the Philosophy of Language, Cambridge: Cambridge University Press.

OdrowĄż-SyPNIEwsKa J., 2016., Wprowadzenie, w: J. Odrowąż-Sypniewska (red.), Przewodnik po filozofii języka, Kraków: Wydawnictwo WAM, s. 7-16.

OdrowĄż-SyPNIEWSKa J., (red.), 2016, Przewodnik po filozofii języka, Kraków: Wydawnictwo WAM.

Pigliucci M., 2017, Philosophy as the Evocation of Conceptual Landscapes, w: R. Blackford i D. Broderick (red.), Philosophy's Future. The Problem of Philosophical Progress, Hoboken, NJ: Wiley Blackwell, s. 75-90.

Prechtl P., [1998] 2007, Wprowadzenie do filozofii języka (tłum. J. Bremer), Kraków: Wydawnictwo WAM.

PrzyŁęBSKi A., 2019, Hermeneutyka. Od sztuki interpretacji do teorii i filozofii rozumienia, Poznań: Zysk i Ska Wydawnictwo.

RoRTy R., 1967, Introduction. Metaphilosophical Difficulties of Linguistic Philosophy, w: R. Rorty (red.), The Linguistic Turn. Recent Essays in Philosophical Method, Chicago \& London: University of Chicago Press, s. 1-39.

RorTy R., 1992, Twenty-five Years After, w: R. Rorty (red.), The Linguistic Turn. Recent Essays in Philosophical Method. With Two Retrospective Essays, Chicago \& London: University of Chicago Press, s. 371-374.

Rotter K., 1997, Próba gramatyki filozoficznej. Antologia, Wrocław: Wydawnictwo Uniwersytetu Wrocławskiego.

RotTer K., 2006, Gramatyka filozoficzna $w$ dobie sporu o podstawy matematyki. Eseje o drugiej filozofii Wittgensteina, Opole: Wydawnictwo Uniwersytetu Opolskiego.

Russell G., 2012, Introduction, w: G. Russell, D. G. Fara (red.), The Routledge Companion to Philosophy of Language, New York \& London: Routledge, s. 1-6.

Russell, G., Fara D. G., (red.), 2012, The Routledge Companion to Philosophy of Language, New York \& London: Routledge.

SAUSSURE de F., [1916] 1991, Kurs językoznawstwa ogólnego, wydanie drugie, poprawione (tłum. K. Kasprzyk), Warszawa: PWN. 
Scholz B. C., Pelletier F. J., Pullum G. K., 2020, Philosophy of Linguistics, w: E. N. Zalta (red.), The Stanford Encyclopedia of Philosophy (Summer 2020 Edition), [online:] https://plato.stanford.edu/archives/sum2020/entries/linguistics/ [15.04.2021].

Searle J., [1969] 1987, Czynności mowy. Rozważania z filozofii języka (tłum. B. Chwedeńczuk), Warszawa: Instytut Wydawniczy PAX.

SeArle J., [2004] 2010, Umyst. Krótkie wprowadzenie (tłum. J. Karłowski), Poznań: Rebis.

SŁAPeK D., 2017, Rozważania metajęzykoznawcze. (Studia z metodologii i filozofii językoznawstwa 4), Łódź: Zakład Językoznawstwa Angielskiego i Ogólnego UŁ i Primum Verbum.

Soames S., 2010, Philosophy of Language, Princeton and Oxford: Princeton University Press.

Stalmaszczyk P., 2011, Historyczne i metodologiczne uwarunkowania współczesnego generatywizmu, Linguistica Copernicana 5, s. 13-30.

STALMASzczYK P., 2018a, Współczesna analityczna filozofia języka: wybrane zagadnienia, Diametros 56, s. 129-139.

Stalmaszczyk P., 2018b, O paradygmatach w językoznawstwie (na przykładzie językoznawstwa generatywnego), Linguistica Copernicana 15, s. 37-59.

Stalmaszczyк P., 2021, Szkice z metodologii językoznawstwa i filozofii języka, Łódź: Wydawnictwo Uniwersytetu Łódzkiego.

Stalmaszczyk P., (w druku), Philosophy of Language: Definitions, Disciplines and Approaches, w: P. Stalmaszczyk (red), The Cambridge Handbook of the Philosophy of Language, Cambridge: Cambridge University Press.

STAnosz B., 1991, 10 wykładów z filozofii języka (Biblioteka Myśli Semiotycznej 19), Warszawa: Polskie Towarzystwo Semiotyczne.

Strawson P. F., [1992] 1994, Analiza i metafizyka. Wstęp do filozofii (tłum. A. Grobler), Kraków: Wydawnictwo Znak.

Swiggers P., 1996, XXth-Century Theories of Language: An Epistemological Diagnosis, Linguistica 36 (1), s. 3-16.

Szabó, Z. Gendler, Thomason R. H., 2019, Philosophy of Language, Cambridge: Cambridge University Press.

SzoŁtyseK A. E., 2021, Filozofia języka. Kształtowanie myśli, Kraków: Impuls.

Talasiewicz M., 2006, Filozofia sktadni, Warszawa: Wydawnictwo Naukowe Semper.

TAYLOR Ch., 2016, The Language Animal. The Full Shape of the Human Linguistic Capacity, Cambridge, MA - London: The Belknap Press of the Harvard University Press.

TOKARSKI R., 2013, Światy za słowami. Wykłady z semantyki leksykalnej, Lublin: Wydawnictwo UMCS. 
Vendler Z., 1974, Linguistics in Philosophy, Ithaca \& London: Cornell University Press.

Williamson T., 2004, Past the Linguistic Turn?, w: B. Leiter (red.), The Future for Philosophy, Oxford: Clarendon Press, s. 106-128.

Wittgenstein L., [1953] 2000, Dociekania filozoficzne (tłum. B. Wolniewicz), Warszawa: Wydawnictwo Naukowe PWN.

WoleŃSKi J., [2005] 2014, Epistemologia, Warszawa: Wydawnictwo Naukowe PWN.

WolEŃski J., 2019, Ograniczenia semantyki formalnej (logicznej), Studia Semiotyczne 33 (2), s. 231-244.

ZiembiŃsKi Z., [1959] 2002, Logika praktyczna. Wydanie XXV, Warszawa: Wydawnictwo Naukowe PWN.

\section{Key issues in contemporary philosophy of language, philosophy of linguistics, and linguistic philosophy ( s u m mary)}

The article discusses key concepts in contemporary philosophy of language (especially analytic), and also philosophy of linguistics, and linguistic philosophy, and the relations between these domains. Whereas linguistics, the scientific study of language, is concerned with theoretical and applied analyses of human natural language and with constructing appropriate levels of linguistic representation, philosophy of language provides (philosophical) investigations into the phenomenon of language in general, concentrating especially on the problems of meaning, reference, truth, and understanding. More recent approaches to philosophy of language considerably extend this field of investigation. Linguistic philosophy can be described as an approach to the philosophy of language, a philosophical method; further on, philosophy of linguistics offers philosophical reflections on linguistic inquiries and linguistic theories. The article investigates mutual relations among these disciplines, offers necessary terminological clarification, and provides an overview of recent studies devoted to philosophy of language.

Keywords: analytic philosophy; philosophy of language; philosophy of linguistics; linguistic philosophy; theory of language; linguistic methodology; semantics; pragmatics 
